Article

\title{
What Influences the Servitization Process the Most? A Perspective of Polish Machinery Manufacturers
}

\author{
Justyna Kozlowska $\mathbb{D}$ \\ Faculty of Engineering Management, Bialystok University of Technology, 15-351 Bialystok, Poland; \\ j.kozlowska@pb.edu.pl
}

Received: 2 May 2020; Accepted: 17 June 2020; Published: 21 June 2020

\begin{abstract}
The servitization of manufacturing is an increasingly popular way to win market competition and maintain this advantage as well as to ensure more sustainable development of the manufacturing sector. To make this strategy effective, many aspects should be considered. This study mainly aims to identify the most significant factors influencing the process of servitization in the manufacturing sector. An additional research problem that emerged in the research process was aimed at determining the factors perceived by entrepreneurs as more important compared to others, and, correspondingly, the reasons behind such differences of opinion. This article is supported by the results of a literature review, the outcomes of a questionnaire survey (conducted with 150 Polish machinery manufacturers), and the findings of in-depth interviews with experts. In the light of the results of the quantitative research, the most important aspects that determine the servitization process are customer requirements and preferences; economic and financial aspects; added value for the customer and the company; and also the relations, stakeholders and partners of the service processes. More specific determinants, such as long-lasting and stronger relationships, organizational strategy, legal regulations regarding the provision of long-term services, and the economic benefits of service recipients, were indicated by experts as crucial in product-service integration. Also, employees' competencies were emphasized as vital for extending the service activity of manufacturing companies. The contribution of this study is twofold. First, it identifies the most important aspects for the analysis of a manufacturer starting out on the servitization path. Second, the study reveals differences in the perception of the importance of certain factors that appear to be related to the experience related to the provision of services by machine manufacturers. Hence, some practical guidelines may be drawn for managers of manufacturing companies who plan to extend their service offer.
\end{abstract}

Keywords: servitization; product-service integration; manufacturing; servitization determinants

\section{Introduction}

The servitization of manufacturing is a trend which involves manufacturing companies introducing increasingly more service components into their offer [1]. Thus, it describes the growing share of service activity within the manufacturing sector, which may be observed in most economies worldwide [2]. Considering the outcomes of business activity, "servitization" is defined as an integrated package consisting of both goods and services [3]. In the process approach, "servitization" is described as a process of change in which manufacturing companies adopt new business orientation models for the provision of services. They develop the offer by a higher number of more advanced services to meet customer needs, achieve a competitive advantage and increase the efficiency of operations [4]. In the literature, several other terms are used to describe this concept, for example, the product-service system [5], hybrid offerings [6], product and service integration [7]. In this paper, the terms "servitization" and "product-service integration" are used interchangeably. Manufacturing companies seek new solutions to build a competitive advantage. Typically, they extend their service 
offer to stand out in the market. Examples like IBM, Rolls-Royce Aerospace, or Xerox are among the most commonly used in the literature as examples of manufacturers who turn into service and solution providers rather than product sellers [8-10].

The value proposition decides on customer choices in a competitive environment [11]. In the manufacturing sector, compared to a purely physical product sale, the integration of products and services means creating new value-added for clients. Services in manufacturing companies can only be an addition to a basic production or sales process (such as transportation of a purchased product or training in its use). However, they can also constitute an essential offer with the material product as an element (for example, the Rolls-Royce "power per hour" service, in which the user only pays for the actual time of the aircraft engine operation).

Despite the widely discussed benefits and the presentation of good practice in the introduction of services to the offer of manufacturing enterprises [12-14], some authors also indicate weaknesses and errors of the proposed integration processes $[15,16]$. In the product and service integration process, sources of failure, i.e., the phenomenon of "service paradox", may be located both within the organization and in its external environment. In the opinion of many authors, the process of implementing changes focused on product and service integration in an enterprise must be preceded by an accurate planning process, including strategic planning [17-19]. The identification, analysis and assessment of factors that determine the course of product and service integration should be the subject of strategic analysis, which is then a premise for the design and implementation of the product and service integration strategy in an enterprise. This was the main prerequisite for this study. The literature review revealed that the servitization process in a manufacturing company is determined by many different factors (technical, economic, legal, etc.) and different types of influence (internal and external). The analysis of the scientific literature and the synthesis of acquired knowledge led to the following conclusions: factors determining the servitization process may be separated in two groups, namely, (i) determinants of decision-making regarding product and service integration (the category of benefits and barriers) and (ii) determinants of the successful servitization process (the category of success factors and reasons for failures). More details about the factors that determine servitization are included in Section 3 of this article. Both groups influence the final outcome of product-service integration. Most factors described in the literature were exposed as a result of case studies or interviews with manufacturers or managers. Although qualitative methods give a more accurate picture of the analyzed phenomenon in a certain case, quantitative research gives a more general picture of the analyzed phenomenon in the studied population. In the area of determinants for the servitization of manufacturing, a gap in quantitative studies was discovered. In particular, no studies were found assessing the level of significance of the servitization process determinants from the manufacturer's point of view. The results of such research will be an original contribution of new knowledge in the field of servitization. In particular, the opinions of manufacturers with more experience in service provision would be a reliable and helpful guide for managers who begin service activity and face difficult decision-making problems related to planning and designing the servitization in their companies. This was an additional premise of this study.

Many studies on servitization are conducted in well-developed countries where the product-service integration is more advanced, e.g., [20-22]. In those countries, manufacturing companies represent a higher level of technological, organizational, and business-culture capacity. Conditions for the development of the servitization process vary depending on the country. Many differences may be observed while comparing markets in well-developed and developing countries [23]. The Polish market tends to follow global trends; however, its level of servitization in the manufacturing sector is still rather lower than in other well-developed economies. According to the author's research (a pilot study) carried out in 2016, which included the analysis of offers (in generally available catalogs, documents, and websites) by 100 enterprises of the Polish machinery sector, less than $10 \%$ of enterprises in the research sample offered extensive packages containing more than six types of services. But, at the same time, $90 \%$ of entrepreneurs permanently offered from one to five different types of services to their clients [24]. This demonstrates that 
the enterprises already have some experience in service provision and continue developing this activity. Consequently, a survey conducted in the Polish market can result in interesting insights into the field of research on determinants of servitization. It was an additional premise of undertaking such research in Poland.

To sum up, the research problem was formulated in the form of two research questions:

RQ1: What factors influence the servitization process the most in the opinion of manufacturing companies?

RQ2: What generates potential differences in the assessment of the importance of certain factors?

The paper is organized as follows. First, the methodology of the research process is described. In the next section, the literature review results are presented. Then, research results are described and discussed. Finally, the conclusions and the potential direction for future research are indicated. This research is a part of a wider study conducted within the frame of the scientific project entitled "Methodology of strategic analysis of the company for the purposes of product-service integration" financed by the National Science Centre of Poland.

\section{Methodology of the Study}

The study aimed to identify the most significant factors that determine the servitization process in the manufacturing sector, particularly factors perceived as more important by the Polish manufacturers. This information would have great practical value for managers of manufacturing companies that plan to extend their offerings by adding more services or integrating services with manufactured products either to satisfy customer needs or just to advance their business. The research process of this study consisted of four steps (Figure 1).

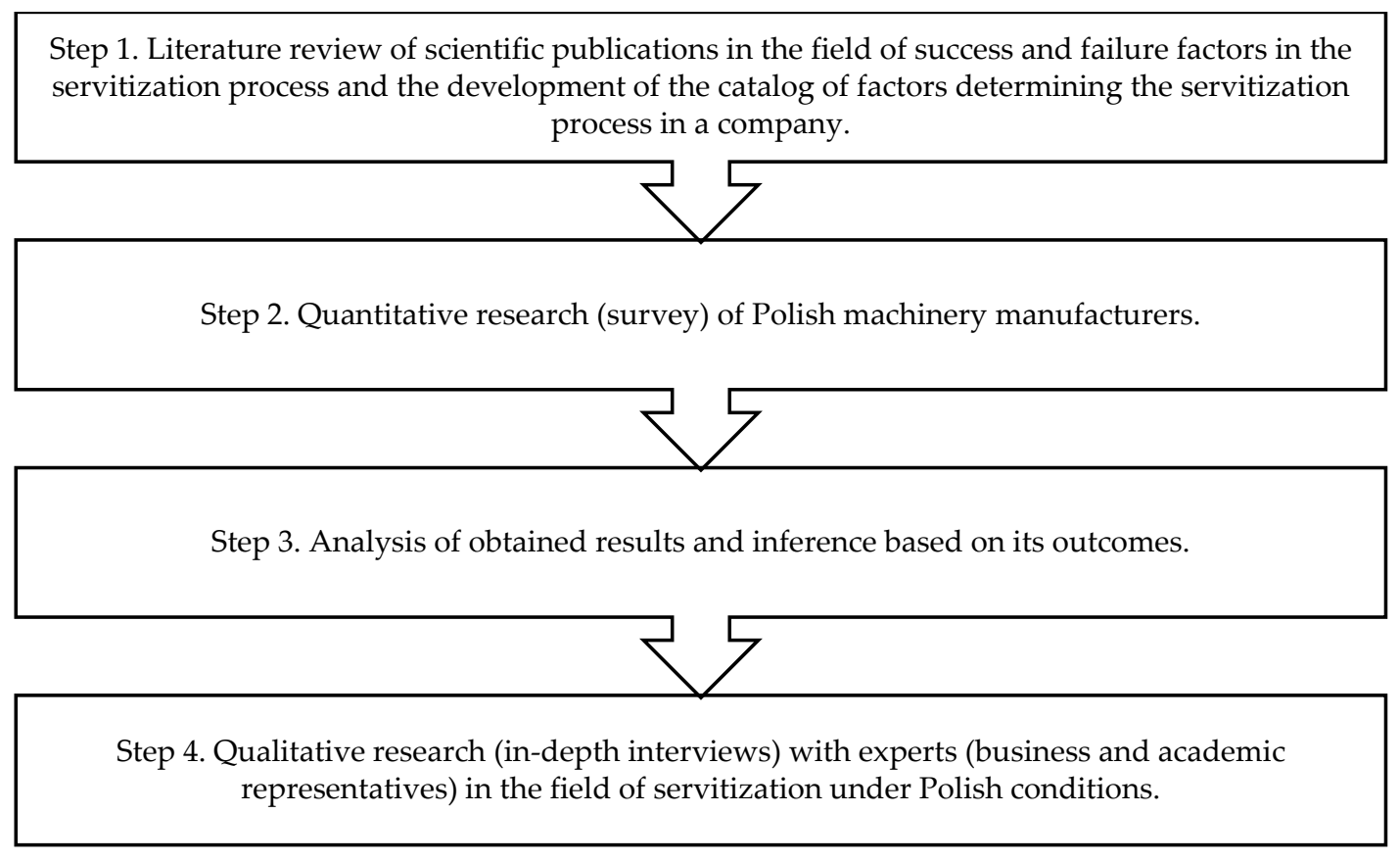

Figure 1. The methodology of the study.

Step 1 was the literature review, which was carried out in the field of servitization, product-service systems, and the product-service integration. The review was conducted mainly based on the content of three scientific databases: Scopus, Web of Science and Science Direct. Particular attention was given to factors that play a crucial role in the process of extending the service offerings by manufacturers, and success and failure determinants. Based on the literature review, a vast range of factors were identified. Factors were different in terms of nature, their influence on the servitization process and the company's activity. Therefore, in the next step, the catalog of factors was developed. It was presented 
in detail in another author's publication [25]. For quantitative research, the factors were grouped into nine general determinants.

Step 2 involved surveying 150 Polish machinery manufacturers using the Computer-Assisted Telephone Interviewing (CATI) technique. The object of the author's interest was the machinery and equipment manufacturing industry because the literature review showed that it was one of the most studied industry sectors in terms of servitization. The machine industry represents a mature level of technological development with relatively slow growth in the market and a lengthy introduction of technological innovations. As a result, companies in this industry relatively often try to increase their profitability using services; thus, they quickly enter the path to product and service integration [26]. According to the results of the report by Mitsubishi Electric Europe B.V. (LLC Balice, Poland), the machinery sector is one of the most innovative industries, and the trump card of Polish producers in competition with cheap industrial machines, for example, those produced in China, are services, such as the possibility to finance a purchase in cooperation with leasing companies, excellent warranty and post-warranty services, and the option to repair machines and extend their life [27].

Step 3 of the study included analyses of the survey results using statistical measures and methods. First, the most popular statistic measures (mean, standard deviation, coefficient of variation) were calculated to deliberate on the general conclusion about the importance of factors. Then, considering high values of standard deviation for some factors, a cluster analysis was conducted. The results of the cluster analysis allowed capturing the differences in average assessments of individual factors and characterizing each group. Particular attention was paid to groups of companies whose assessments differed significantly.

In Step 4, qualitative research (in-depth interviews) was conducted in two groups of respondents. The first group were experts from the academic community with research interests directly or indirectly related to servitization. The second group consisted of representatives of the management staff of large and medium-sized enterprises in the machinery sector, which had been operating in the Polish machinery market for several decades and had practical experience in service provision. Respondents from the academic community had at least several years of experience in observing and analyzing the economic situation of the Polish market in general and the industrial sector in particular (Expert No. 1, Expert No. 2 and Expert No. 3). The business community was represented by experts who:

- Originated from medium or large enterprises offering services of various scope to their clients;

- Performed managerial functions in their organization;

- Had at least five years of industry experience.

The participants in the in-depth interviews were manufacturers of CNC (Computerized Numerical Control) machine tools (Experts No. 4 and 5), a large manufacturer of industrial furnaces (Expert No. 6), a medium-sized manufacturer of agricultural machinery (Expert No. 7), a medium-sized manufacturer of machinery for the food industry (Expert No. 8), a large enterprise producing waste sorting and processing machines (Expert No. 9) and a large manufacturer of metal processing and metallurgy machinery (Expert No. 10). Experts were asked for their opinions on the aspects which could generate more or less favorable conditions for product-service integration.

\section{Theoretical Background and the Results of the Literature Review}

The servitization of operations in a manufacturing company is perceived as a business strategy that enables a company to gain a long-lasting competitive advantage and a method to meet high customer requirements. From a manufacturer's perspective, it means offering higher-value solutions that differentiate the company among its competitors. The advantage is that service-based offerings are more difficult to copy by competitors than a technical or technological improvement of the product, so a manufacturer may evolve from a leader in technology to a leader in the use of products [13]. From the customer point of view, it is a chance to avoid many different obligations associated with product 
ownership. For society as a whole, the servitization of manufacturing companies is a more balanced approach to business [28]. For manufacturers, the main drivers behind the extension of service offerings are the benefits that may be accrued by clients from new value propositions. The basic benefits resulting from product and service integration are the relationships with different stakeholders. On the one hand, long-term service contracts between the manufacturer and the product user build loyalty and trust between customers and suppliers [29]. On the other hand, the provision of services creates and strengthens alliances with other partners involved in service processes. The services offered are more flexible than products, so they can be better tailored to customer needs [30]. This requires continuous improvement of products and services, introducing innovations and monitoring their quality, which directly translates into increased customer satisfaction [29]. The advantage of using advanced service functions in the manufacturing sector, such as product-oriented or result-oriented services, is the reduction of the administrative burden. It is related to the transfer of ownership and rights to the customer or back to the manufacturer in the case of products that require controlled disposal (such as equipment containing electronic circuits). The beneficial impact of product and service integration on the natural environment results, among other things, in greater responsibility of the manufacturer for the offered products, for example, by providing access to services like recycling and the recovery of waste after the end of the product's life-cycle [31]. The manufacturer must use better quality and more efficient resources and materials in the manufacturing process so that a material product could be a source of long-term revenue (for example, through leasing or renting) [32]. Changing the approach to planning and design of product life-cycle, which is the result of product and service integration, can, therefore, lead to the optimization of production as well as to the reduction of resource consumption and the amount of waste generated due to the reduction in production [28]. This constitutes both the substantial benefit as well as a driver for servitization.

Despite the enormous potential of product and service integration, the number of production organizations that successfully apply service strategies is not as large as it may seem [26], and the benefits of providing high-quality services are not always achievable. Many enterprises fail to obtain the expected level of revenue growth from the expansion of service activities. Often, the costs of providing services far exceed the expected revenues. In the literature, this phenomenon is called the "service paradox" or "servitization paradox" $[15,16]$ and may be caused by many factors. Foremost, internal resources determine the capabilities of the organization for successful product and service integration. A manufacturer must have sufficient resources and capabilities to integrate the knowledge about the production of products and the provision of services in a way that ensures the proper functioning of new solutions [33]. Competences and capabilities to develop and deploy resources in the field of service provision are an essential element of an organization, thanks to which producers of physical products can successfully undergo the process of product and service integration and by this action affect the achievement of competitive advantage [6]. Some authors point out that the infrastructure for service provision, the integrated process of product and service development, and the technical capability of data processing play a vital role as a success factor for servitization in the manufacturing sector $[34,35]$. But the reasons behind the "service paradox" may also originate outside the organization, in the enterprise's environment [36]. Relationships with external partners play a key role in the product and service integration process. This is because the product itself is often supplied by one organization, and the support and services are provided by the partners of the organizations forming the cooperation network, which requires a greater degree of involvement in relationships with all stakeholders. The general industrial environment and even the global economic or financial environment may, to some extent, have a positive or negative impact on the servitization process at the organizational level [37]. According to some authors, the customer is always the key aspect. Insufficient knowledge of the client needs, their requirements and the level of expected value, as well as the lack or incorrect assessment of the level of client knowledge, their processes or strategy of operation, may, in turn, cause a failure in the process of servitization. Customers will not be interested in integrated solutions or services if the expected value of the solution is too low for them, it is not 
suited to their operational strategy or is too different from the current offer [38]. The implementation of services requires direct contact between the service provider and the service user. The active role of the client in the process of creating and experiencing or "consuming" the service requires a restrictive location of its provision because this process must take place, at least partly, in the presence of the client. The effect of integrating the external factor is the heterogeneity of all service activities. This means that the manufacturer must meet different expectations of all stakeholders involved in the process of service provision, such as adjusting the time schedules of all participants in the process [13]. The observation of manufacturers approaching service-oriented business models shows that long-term relationships between a service provider and a customer or a user require a higher level of mutual trust than a short-term sale transaction. Also, industrial entrepreneurs are afraid of greater risk associated with the adoption of a new pricing policy, the lack of experience in designing and providing services, and changes in the area of business management. The market of integrated and system solutions, which emerged because of product and service integration, has a relatively low level of maturity. Hence, users and clients are not always enthusiastic about new forms of product use without acquiring rights to their property and prefer traditional transaction models [39].

In a global context, political and legal factors can both impede or support the product and service integration processes. Political and legal conditions may prevent the operation of partner networks in the group that involve a producer, local supplier and customers, and which are built for the more efficient functioning of service processes. Also, the lack of compliance with local rules or other regulations for the provision of services that offer integrated comprehensive product and service solutions may hinder the cooperation between partners in the network built as part of the product and service system. In other cases, again, a national or global policy can be a factor in facilitating product and service integration processes. The concept of sustainable development and programs endorsing ecological activities or innovation are important factors that support the servitization of manufacturing activities [40].

To sum up, product and service integration can lead to a wide range of benefits, but its successful implementation depends on many different factors and a company's resources. Benefits may be characterized by a lower or higher level of value as well as the various impact on the process of servitization of the manufacturing company's activity. Consequently, they constitute more or less favorable conditions for the servitization process. The literature overview and the synthesis of its results enabled the formulation of lists of profits and success factors that determine the process of servitization in a manufacturing company.

Direct profits for manufacturers, which stem from providing services, include:

- An improvement in customer relationships thanks to more frequent and more prolonged contacts and a constant flow of information about consumer preferences [29];

- An increase in the total value for the client due to the enlarged number of services and service components, which include activities and schemes that result in the extension of the lifetime of existing and operating products (through improvement and modernization) and the extension of the usefulness of the product and materials from which it was made after the end of the use cycle (the recycling and the re-use of a part of or the whole product) [31];

- A diversification of the market offering and a stable source of revenues and higher profit margins [26,41];

- A possibility to compete based on knowledge rather than cost and to create considerable added value for both suppliers and their customers [7];

- Greater flexibility of the offer, so it can be easier adapted to customer needs or tailored to client requirements [30];

- A positive impact on the natural environment, including a greater responsibility of the producer for the products offered, for example, by providing access to the collection, recycling, and recovery services after the end of the product life-cycle [32]; 
- The optimization of the reduction in production costs as well as the reduction of the resource consumption and the amount of waste generated due to changes in the approach to planning and designing the product life-cycle and the resulting technical and technological changes in the manufacturing process [28].

The outcome of product-service integration is also influenced by the following success factors:

- Resources and assets related to the research and development of products, services, and manufacturing [6];

- Technical aspects of service provision, such as designing and engineering, and processing the information related to service provision [6];

- The capability to integrate knowledge from various areas of the company's operation [42];

- Knowledge of customer needs, their requirements and the level of expected value [38];

- Social acceptance, the ecological awareness of the society, and the openness to innovation, especially at higher levels of product and service integration $[5,28,43]$;

- Political and legal conditions in the local and global market [40];

- Technical aspects pertaining to the processes of planning, designing, and developing products and services as well as the approach to the integration of product and service production processes [13,44].

As a synthetic result of the literature review presented in this section, the author formulated the following nine general factors to be examined:

1. Customer requirements and preferences;

2. Added value for the customer and the company;

3. Economic and financial analysis;

4. Relations, stakeholders and partners in service processes;

5. Costs of delivery and provision of services;

6. Technical organization of service processes;

7. Technical and organizational aspects of the integration of production and service processes;

8. Ecological aspects of production and service activities;

9. Legal conditions for the provision of services.

The above nine aggregated factors cover most of the aspects indicated in the literature as determinants affecting the process of servitization. Therefore, they were included in the survey study for the evaluation in terms of their importance in the product and service integration from the point of view of manufacturers. This knowledge about the importance of certain factors could be a starting point for the analysis and assessment of company chances for a successful product-service integration, which would facilitate the decision-making process.

\section{Empirical Study Results}

\subsection{Survey Research Results}

The survey involved 150 companies from the Polish machine production sector, located and operating throughout the country. Respondents were chosen randomly from the database of Polish manufacturers registered under the category of "manufacture of machinery and equipment". Under this category, over 9000 companies are registered, so the sample is representative of the machinery manufacture sector. The largest number of surveyed enterprises (38\%) declared the manufacturing of general-purpose machinery. According to the Polish classification of business activity, this group includes manufacturers of engines and turbines (excluding aircraft, car and motorcycle engines); equipment and accessories for a hydraulic and pneumatic drive; other pumps and compressors; bearings, gearing and driving elements; furnaces and furnace burners; lifting equipment; office 
machinery and equipment (excluding computers); mechanical hand tools; and industrial refrigeration and ventilation equipment. Enterprises registered as manufacturers of other special-purpose machinery constituted $35 \%$ of the surveyed group. This group included the manufacturers of machinery for metallurgy, mining, and construction; machines used in food, tobacco and beverage production; machines for the textile, clothing and leather industry; and machinery for the paper, rubber and plastic industry. Companies with their activity classified as the production of agricultural and forestry machinery represented $13 \%$ of the research sample, whereas manufacturers of mechanical machines and tools represented 11\%. Finally, about 3\% of surveyed enterprises chose the answer "other", declaring, for example, activities in the field of energy or mining machinery production. The analysis of the research sample, in terms of the geographical scope of economic activity, showed that for $86 \%$ of respondents, the dominant market was the domestic market. At the same time, over $50 \%$ of enterprises indicated having some activity in the European market, and only $3 \%$ operated within a commune or city. According to the results of the study, over $80 \%$ of the machine and device manufacturers offered their clients services related to manufacturing activity. About $5 \%$ of the surveyed enterprises provided services unrelated to the production activity, indicating, for example, services related to industrial automation, electrics, or zinc coating of steel structures. Enterprises that did not provide any services accounted for $13 \%$ of the research sample. Over $95 \%$ of surveyed companies sold the manufactured machines and devices as well as services on the B2B (business-to-business) market. Approximately 33\% of respondents also addressed individual clients, while $21 \%$ of producers indicated public benefit entities among their clients.

All respondents were asked about the importance of the factors that influence the servitization process to learn the opinions of manufacturers with various approaches to service provision. The study exposed that Polish machinery manufacturers considered all factors as extremely important for the product and service integration. A mean value calculated for all factors equaled 6.10 (Table 1) on a seven-point scale. However, as the most important factors respondents indicated customer requirements and preferences (the average importance ratings of 6.66); added value for customers and the company (the importance on the level of 6.61 on average); economic and financial analysis (ratings of 6.55 on average); and also relations, stakeholders and partners in service processes (with the average importance ratings equal to 6.31). The coefficient of variation shows that for some factors, the opinions of respondents varied insignificantly (11-14\% on average). For other factors, the opinions were a bit more dispersed (from 20 to $31 \%$ ).

Table 1. Statistical measures of researched factors.

\begin{tabular}{lccc}
\hline \multicolumn{1}{c}{ Factor Description } & Average & Standard Deviation & Coefficient of Variation \\
\hline (1) Customer requirements and preferences & 6.66 & 0.74 & $11 \%$ \\
\hline (2) Added value for the customer and the company & 6.61 & 0.926 & $14 \%$ \\
\hline (3) Economic and financial analysis & 6.55 & 0.887 & $14 \%$ \\
\hline $\begin{array}{l}\text { (4) Relations, stakeholders and partners in } \\
\text { service processes }\end{array}$ & 6.31 & 1.337 & $21 \%$ \\
\hline $\begin{array}{l}\text { (5) Costs of delivery and provision of services } \\
\text { (6) Technical organization of service processes }\end{array}$ & 5.95 & 1.358 & $23 \%$ \\
\hline $\begin{array}{l}\text { (7) Technical and organizational aspects of the } \\
\text { integration of production and service processes }\end{array}$ & 5.91 & 1.449 & $25 \%$ \\
\hline $\begin{array}{l}\text { (8) Ecological aspects of production and } \\
\text { service activities }\end{array}$ & 5.87 & 1.549 & $26 \%$ \\
\hline $\begin{array}{l}\text { (9) Legal conditions for the provision of services } \\
\text { Average values }\end{array}$ & 5.17 & 1.392 & $24 \%$ \\
\hline
\end{tabular}


The lowest level of importance was given to technical and organizational aspects of the integration of production and service processes, ecological aspects of production and service activities, and legal conditions for the provision of services (Figure 2).

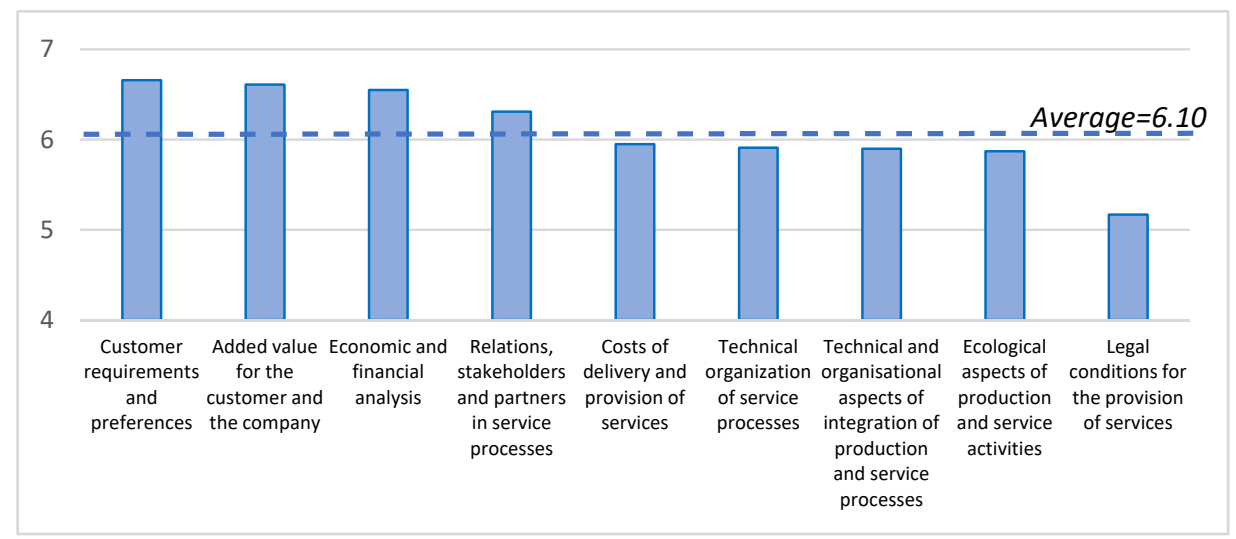

Figure 2. Importance of the studied factors—a ranking of the average assessment.

Table 2 shows the percentage distribution of responses concerning the nine factors that determine the product-service integration process. The results indicate that the highest level of importance (note 7) was not only given to Factors 1 and 2, which were considered extremely significant by the majority of respondents (over $70 \%$ of answers), but also to the technical organization of service processes (Factor 6), which was regarded by the $65 \%$ of manufacturers as very important. However, Factor 6 assessments were more diverse (the coefficient of variation amounted to $25 \%$ ), so the remaining $35 \%$ of the research sample had a somewhat varied opinion on its significance.

Table 2. Distribution of assessments concerning analyzed factors.

\begin{tabular}{|c|c|c|c|c|c|c|c|c|}
\hline \multirow[t]{2}{*}{ Factors Description } & \multicolumn{8}{|c|}{$\begin{array}{l}\text { Q: Please, Assess How Important the Following Factors Are in the } \\
\text { Servitization of Manufacturing Companies on a Seven-Point Scale, } \\
\text { Where 7-Very Important, 1-Definitely Not Important }\end{array}$} \\
\hline & 1 & 2 & 3 & 4 & 5 & 6 & 7 & SUM \\
\hline $\begin{array}{l}\text { (1) Customer requirements } \\
\text { and preferences }\end{array}$ & $0.7 \%$ & $0.0 \%$ & $0.0 \%$ & $0.7 \%$ & $4.0 \%$ & $20.0 \%$ & $74.7 \%$ & $100 \%$ \\
\hline $\begin{array}{l}\text { (2) Added value for the customer } \\
\text { and the company }\end{array}$ & $0.7 \%$ & $0.0 \%$ & $0.7 \%$ & $1.3 \%$ & $8.7 \%$ & $17.3 \%$ & $71.3 \%$ & $100 \%$ \\
\hline (3) Economic and financial analysis & $2.7 \%$ & $0.7 \%$ & $1.3 \%$ & $6.7 \%$ & $19.3 \%$ & $21.3 \%$ & $48.0 \%$ & $100 \%$ \\
\hline $\begin{array}{l}\text { (4) Relations, stakeholders and } \\
\text { partners in service processes }\end{array}$ & $3.3 \%$ & $0.7 \%$ & $2.0 \%$ & $9.3 \%$ & $12.7 \%$ & $24.7 \%$ & $47.3 \%$ & $100 \%$ \\
\hline $\begin{array}{l}\text { (5) Costs of delivery and provision } \\
\text { of services }\end{array}$ & $4.7 \%$ & $0.7 \%$ & $2.0 \%$ & $8.0 \%$ & $12.0 \%$ & $22.7 \%$ & $50.0 \%$ & $100 \%$ \\
\hline $\begin{array}{l}\text { (6) The technical organization of } \\
\text { service processes }\end{array}$ & $3.3 \%$ & $1.3 \%$ & $0.0 \%$ & $2.7 \%$ & $6.7 \%$ & $20.7 \%$ & $65.3 \%$ & $100 \%$ \\
\hline $\begin{array}{l}\text { (7) Technical and organizational } \\
\text { aspects of the integration of product } \\
\text { and service processes }\end{array}$ & $6.0 \%$ & $1.3 \%$ & $3.3 \%$ & $16.0 \%$ & $30.0 \%$ & $19.3 \%$ & $24.0 \%$ & $100 \%$ \\
\hline $\begin{array}{l}\text { (8) Ecological aspects of production } \\
\text { and service activities }\end{array}$ & $2.7 \%$ & $0.7 \%$ & $3.3 \%$ & $7.3 \%$ & $14.7 \%$ & $28.7 \%$ & $42.7 \%$ & $100 \%$ \\
\hline $\begin{array}{l}\text { (9) Legal aspects of the provision } \\
\text { of services }\end{array}$ & $0.7 \%$ & $1.3 \%$ & $0.0 \%$ & $1.3 \%$ & $3.3 \%$ & $18.0 \%$ & $75.3 \%$ & $100 \%$ \\
\hline
\end{tabular}

The distribution of ratings for some factors was right-sided (the advantage of high scores), and for others, the assessments were more evenly distributed, showing differences in the views of the producers on these matters. Therefore, a mean and standard deviation of each factor was mapped in 
the two-dimensional plot, which helped to discover variables (factors) that were evaluated on a similar level (namely, the opinions of respondents were homogenous) and that differed more significantly (namely, the opinions were heterogeneous).

Based on the data presented in Figure 3, respondents gave the highest and most consistent score to the importance of the following factors: customer requirements and preferences (a point named client), added value for the customer and the company (a point named values) and economic and financial analysis (a point named economic aspects). High and convergent notes indicate similar opinions among respondents regarding the importance of the three factors named values, client, and economic aspects. They referred to the first three factors from the list, which also had the highest ratings. Therefore, it can be stated that these were undoubtedly the most crucial determinants of the product-service integration process in the opinion of researched companies.

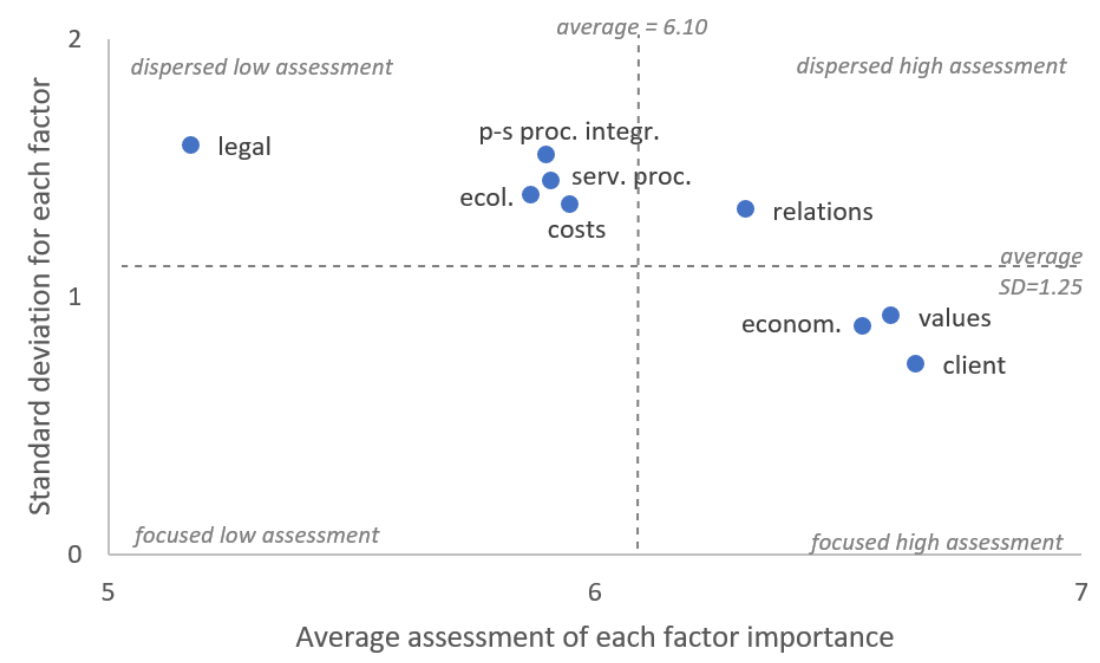

Figure 3. Distribution of the factors determining the product-service integration on the two-dimension plot (the average value and standard deviation).

The importance of relations, stakeholders and partners in service processes also received high assessment (with the average score equal to 6.31), but the options were rather dispersed, showing that for some manufacturers, this aspect seemed to be unimportant, or less important than others. The lowest and the most dispersed ratings were given to the following factors: costs of delivery and provision of services, technical organization of service processes, technical and organizational aspects of the integration of product and service processes, ecological aspects of production and service activities, and legal aspects of the provision of services. It was interesting to learn which companies assessed these factors as less important, and, even more so, why? The analysis of their main characteristics could bring some valuable conclusions about the reasons behind these decisions (lower assessments). Therefore, in the next step, a cluster analysis was conducted to group companies based on similarities in opinions about the factors.

Cluster analysis is a tool for exploratory data analysis which aims to arrange objects into groups in such a way that the degree of object linking in the same group is as large as possible, and with objects from other groups as small as possible [45]. For a more detailed description of this statistical method, refer to references [46,47]. It is often used for the classification of studied objects into groups to distinguish the basic characteristics of each cluster element [48-50]. Using Ward's method and the analysis of the agglomeration process, three clusters of manufacturers were distinguished (Figure 4). 


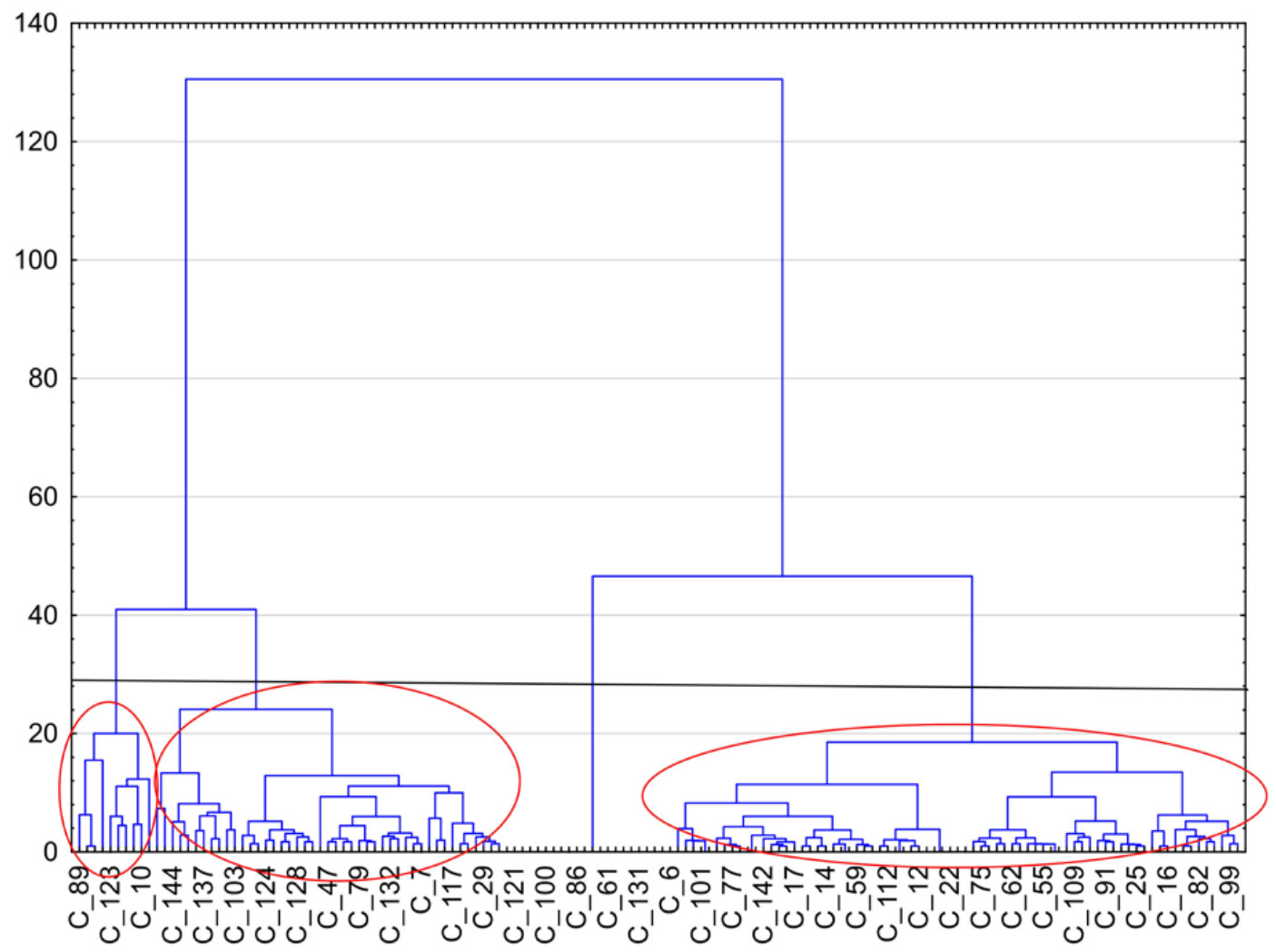

Figure 4. Cluster dendrogram.

Then, with the k-means procedure, three clusters were singled out. Cluster 1 had 62 elements, i.e., about $41 \%$ of the sample. Cluster 2 consisted of 33 companies, which amounted to $22 \%$ of the surveyed group. Cluster 3 included 55 researched manufacturers, which comprised $37 \%$ of the sample. Each cluster was characterized by different levels of the factor assessment (Figure 5). Major differences were found between the average assessment of the importance of each factor in Cluster 2 (red line) and Cluster 3 (green line). Manufacturers in Cluster 2 gave much lower ratings to most of the factors. While the companies in Cluster 3 gave high scores to all studied factors (Table 3). The most significant differences were observed in the means of importance assessment of Factor 5, the costs of delivery and provision of services (the difference equal to 3.01); Factor 7, technical and organizational aspects of the integration of production and service processes (the difference equal to 2.97); and Factor 4, relations, stakeholders and partners in service processes (the difference of 2.86). Considering the scope of the scale (seven-point), these differences are somewhat significant. Technical and organizational aspects of the integration of production and service processes (Factor 7) also had the lowest assessment in Cluster 1. 


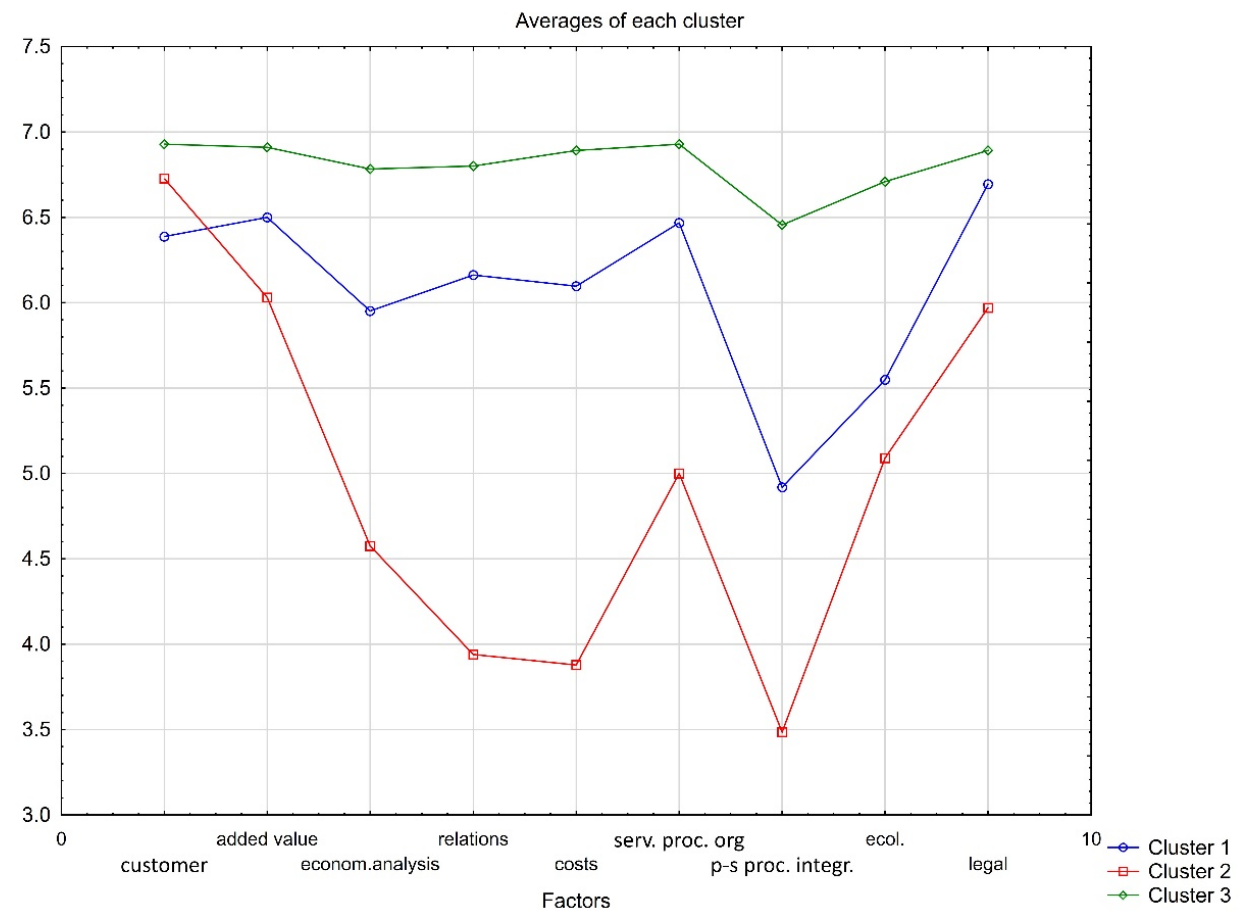

Figure 5. Average assessments of the factors' importance in all three clusters.

Table 3. Assessments of the importance of each factor in clusters-average values.

\begin{tabular}{lccc}
\hline \multicolumn{1}{c}{ Factor Description } & Cluster 1 & Cluster 2 & \multicolumn{2}{c}{ Cluster 3 } \\
\hline (1) Customer requirements and preferences & 6.39 & 6.73 & 6.93 \\
\hline (2) Added value for the customer and the company & 6.50 & 6.03 & 6.91 \\
\hline $\begin{array}{l}\text { (3) Economic and financial analysis } \\
\text { (4) Relations, stakeholders and partners in } \\
\text { service processes }\end{array}$ & 6.95 & 4.58 & 6.78 \\
\hline $\begin{array}{l}\text { (5) Costs of delivery and provision of services } \\
\text { (6) Technical organization of service processes }\end{array}$ & 6.16 & 3.94 & 6.80 \\
\hline $\begin{array}{l}\text { (7) Technical and organizational aspects of the integration } \\
\text { of production and service processes }\end{array}$ & 6.97 & 5.00 & 6.89 \\
\hline $\begin{array}{l}\text { (8) Ecological aspects of production and service activities } \\
\text { (9) Legal conditions for the provision of services }\end{array}$ & 5.55 & 5.93 \\
\hline
\end{tabular}

Consequently, every cluster was analyzed in detail in terms of other information and characteristics that were obtained during the survey. In the context of servitization, an aspect that could influence the assessments of the researched factors was the experience of a company in service provision. This aspect was included in the survey in the form of several questions. Manufacturers were asked about service offerings, namely, the kind of services that they offered and the frequency of each service delivered to their clients. Respondents were also asked about the share of income derived from services in the total income of their company. Clusters were compared based on this information.

The distribution of the companies between clusters in terms of a share of income derived from services in the total revenues of the company is presented in Table 4. Most (74\%) surveyed manufacturers who did not derive any income from service provision were grouped in Cluster 2 . A vast majority (around $60-70 \%$ ) of those manufacturers who reported the highest levels of share $(31 \%$ and more) of service income in the company revenue were grouped in Cluster 3. Likewise, considering 
the structure of each cluster in terms of the same aspect (Table 5), it occurred that Clusters 1 and 2 mostly (approximately $80 \%$ ) consisted of companies that derived less than $20 \%$ of the total income from service provision. About $50 \%$ of companies that were grouped in Cluster 3 obtained $20 \%$ and more of their revenues from service provision.

Table 4. Distribution of companies between clusters in terms of the level of revenues derived from service provision.

\begin{tabular}{ccccc}
\hline \multirow{2}{*}{$\begin{array}{c}\text { Share of the } \\
\text { Service Income }\end{array}$} & \multicolumn{4}{c}{ Percentage of the Companies } \\
\cline { 2 - 4 } & Cluster 1 & Cluster 2 & Cluster 3 & Sum \\
\hline 0 & $16 \%$ & $74 \%$ & $11 \%$ & $100 \%$ \\
$0-15 \%$ & $49 \%$ & $18 \%$ & $34 \%$ & $100 \%$ \\
$15-20 \%$ & $64 \%$ & $18 \%$ & $18 \%$ & $100 \%$ \\
$21-30 \%$ & $33 \%$ & $5 \%$ & $62 \%$ & $100 \%$ \\
$31-40 \%$ & $13 \%$ & $13 \%$ & $75 \%$ & $100 \%$ \\
$41-50 \%$ & $29 \%$ & $14 \%$ & $57 \%$ & $100 \%$ \\
Over 50\% & $40 \%$ & $0 \%$ & $60 \%$ & $100 \%$ \\
\hline
\end{tabular}

Table 5. Structure of each cluster in terms of the share of income derived from services in the total income of the company.

\begin{tabular}{cccc}
\hline Share of the Service Income & Cluster 1 & Cluster 2 & Cluster 3 \\
\hline 0 & $5 \%$ & $42 \%$ & $4 \%$ \\
$0-15 \%$ & $53 \%$ & $36 \%$ & $42 \%$ \\
$15-20 \%$ & $23 \%$ & $12 \%$ & $7 \%$ \\
$21-30 \%$ & $11 \%$ & $3 \%$ & $24 \%$ \\
$31-40 \%$ & $2 \%$ & $3 \%$ & $11 \%$ \\
$41-50 \%$ & $3 \%$ & $3 \%$ & $7 \%$ \\
Over 50\% & $3 \%$ & $0 \%$ & $5 \%$ \\
Sum & $100 \%$ & $100 \%$ & $100 \%$ \\
\hline
\end{tabular}

Nonetheless, it is difficult to notice a clear and obvious relationship between the level of the share of service income and belonging to each cluster only by analysis of the above tables. Therefore, additional statistical analyses were carried out. Since the variables (belonging to the cluster and service income) are categorical, a chi-squared test and a correspondence analysis were conducted. The chi-squared independence test confirmed the existence of a statistically significant relationship between two analyzed variables, namely, belonging to a cluster and the revenue from service provision ( $p$-value lower than alpha level $=0.05$ ). Cramér's $\mathrm{V}$ statistics show that this relationship has moderate strength (Table 6).

Table 6. Summary of the results of the chi-squared test for variables belonging to the cluster and service income.

\begin{tabular}{cccc}
\hline \multirow{2}{*}{ Statistics } & \multicolumn{3}{c}{ Statistics: Service Income (7) x Belonging to the Cluster (3) } \\
\cline { 2 - 4 } & Chi-Squared & $\mathbf{d f}$ & $p$-Value \\
\hline Pearson's Chi^2 & 51.10431 & $\mathrm{df}=12$ & $p=0.00000$ \\
Chi^2 NW & 46.25597 & $\mathrm{df}=12$ & $p=0.00001$ \\
Phi & 0.5836912 & & \\
Coef. of contingency & 0.5041016 & & \\
Cramér's V & 0.4127320 & & \\
\hline
\end{tabular}

The co-occurrence of the categories of each variable was analyzed using the correspondence analysis. This is an exploratory technique for analyzing contingency tables which is used to detect relationships and present the structure of qualitative variables. The purpose of the analysis is to 
reconstruct the distance between points (representing rows and/or columns) in a space with fewer dimensions. This way, it enables to create a simplified mapping of information contained in a large contingency table [51] or analogous tables containing measures of the relationship between variable categories. A detailed description of the method can be found in reference [52]. The analysis results were visualized in a two-dimensional plot (Figure 6). Projecting points on one-, two- or three-dimensional space allows, among other things, to check:

- Distances between points illustrating categories of variables from the projection center, with the points furthest from the projection center bringing the most information about the independence of features;

- The occurrence of categories of the same feature in a short distance or overlap, which means that the numbers of such categories can be combined into one new category of a given feature;

- The location of points describing categories belonging to different characteristics, with particularly strongly related categories being situated closer together, and negatively—further away from each other $[53,54]$.

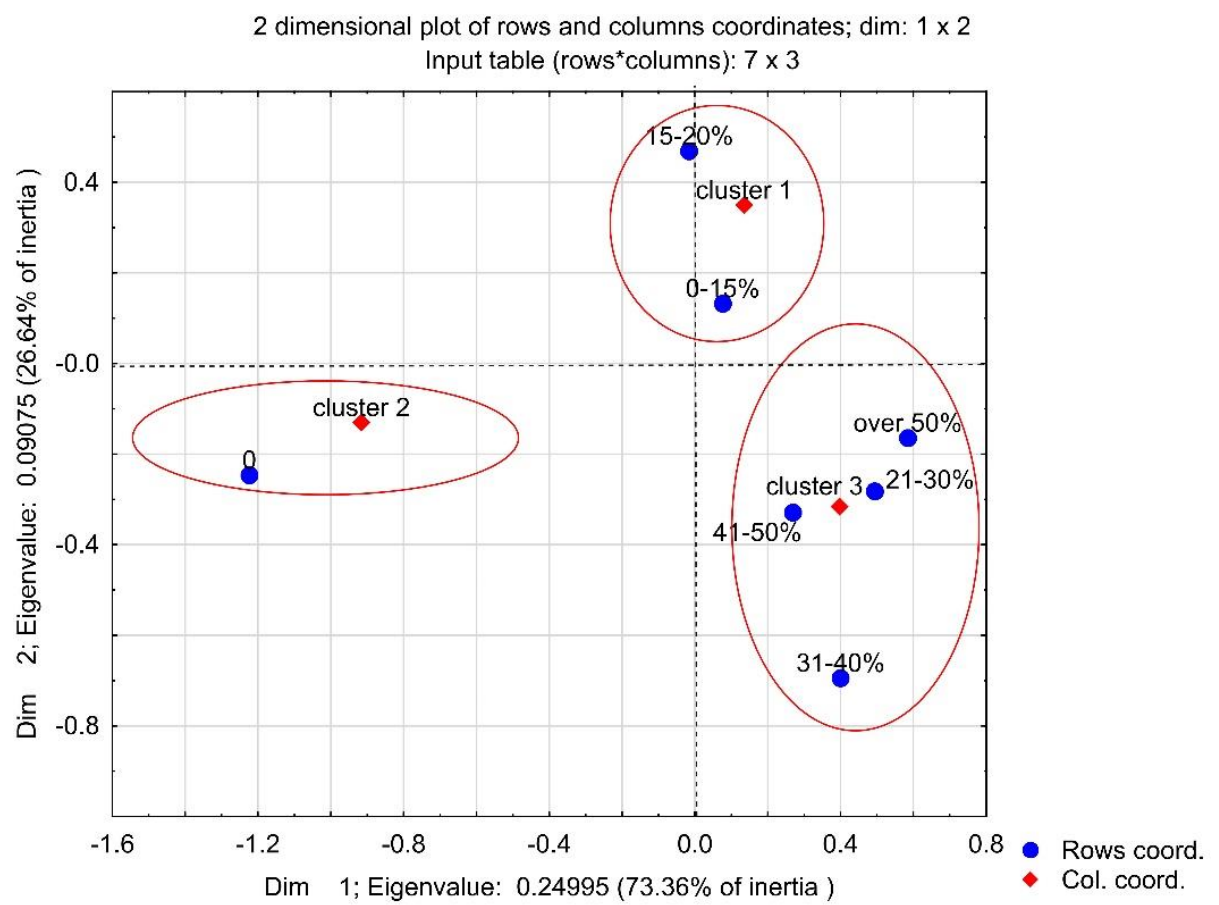

Figure 6. Correspondence analysis results: the map of perception for variables service income and belonging to the cluster.

While analyzing the perception map for service income and belonging to the cluster, the position of points representing each category in relation to point 0 indicates the similarity of categories; or, in other words, a frequency of co-occurrence of the categories in the input contingency table. Thus, it can be stated that for companies grouped in Cluster 3, one respondent mentioned categories "21-30\%", " $41-50 \%$ ", "over $50 \%$ " and " $31-40 \%$ " relatively more frequently as a share of service income in the total company revenue than the rest of the categories of the variable describing income from services. Similarly, if a company belonged to Cluster 1 , it also more frequently reported a share of income derived from services in the total company income (from 0 to 20\%). Finally, companies that were grouped in Cluster 2 most frequently (in relation to Cluster 1 and Cluster 3) indicated obtaining no income from services. In conclusion, Cluster 3 had companies that were more advanced service providers because they usually derived more income from service provision than manufacturers who were grouped in Clusters 1 and 2. 
Subsequently, the service offering of companies included in each cluster was studied. The surveying involved a question about 16 types of services (recognized as most popular in machinery sector according to [24]) and a frequency of provision of each kind of services on a seven-point scale, where 7 meant delivering the service very often (daily), and 1 meant that the service was not provided by the company at all. For the frequency of service provision, arithmetic means were calculated in each cluster (Table 7).

Based on the highest values of means by taking a threshold at 4.0, it is possible to describe service offerings that were the most popular in each cluster. The only services that Cluster 2 companies offered to their clients frequently were warranty and post-warranty services, which were strongly product oriented. So, these manufacturers are focused primarily on the production of goods. Manufacturers who belonged to Cluster 1 proposed more extensive service offerings which included before-sale consultancy, assembly and/or implementation, warranty and post-warranty service, maintenance and technical support, modernization/renovation/regeneration, and industrial services (machining, milling, cutting, bending and other production services). Still, most of these services were product oriented. Manufacturers in Cluster 3 often extended this offering with transport services, training and technical consultancy. Hence, Cluster 3 manufacturers were more willing to offer a wider catalog of customer-oriented services. Also, every mean of service delivering frequency was higher than the same mean of Cluster 1 . Therefore, they not only offered extensive packages of services, but also provided them more frequently.

Table 7. Averages for a frequency of providing each type of services in all clusters (where 7-“we provide the service very often", and 1-“we never provide the service").

\begin{tabular}{|c|c|c|c|}
\hline Type of Service & Cluster 1 & Cluster 2 & Cluster 3 \\
\hline - Before-sale consultancy & 5.5 & 2.4 & 5.7 \\
\hline - Transport & 3.8 & 1.7 & 4.4 \\
\hline - Assembly and/or implementation & 4.3 & 1.9 & 5.2 \\
\hline - Financial support (credit, installments) & 1.2 & 1.3 & 1.3 \\
\hline - Warranty service & 5.7 & 3.2 & 6.1 \\
\hline - Maintenance and technical support & 4.6 & 2.6 & 5.5 \\
\hline - Post-warranty service & 5.5 & 3.2 & 6.0 \\
\hline - Training and technical consultancy & 3.6 & 2.1 & 4.7 \\
\hline - Rental & 1.3 & 1.2 & 1.4 \\
\hline - Leasing & 1.2 & 1.0 & 1.3 \\
\hline - Maintenance & 1.4 & 1.5 & 2.1 \\
\hline - Monitoring and supervision & 2.1 & 1.4 & 2.3 \\
\hline $\begin{array}{l}\text { - Utilization and/or recycling of a used product } \\
\text { (equipment/machinery) }\end{array}$ & 2.3 & 1.5 & 2.4 \\
\hline - Modernization, renovation, regeneration & 4.1 & 2.0 & 4.7 \\
\hline $\begin{array}{l}\text { - Industrial services (machining, milling, cutting, } \\
\text { bending and other production services) }\end{array}$ & 4.3 & 3.0 & 5.6 \\
\hline - Research, expertise & 2.5 & 1.6 & 3.1 \\
\hline Average (frequency) & 3.4 & 2.0 & 3.9 \\
\hline
\end{tabular}

An additional comparison of manufacturer offerings in terms of different kinds of services revealed that over $60 \%$ of companies in Cluster 3 had a broad catalog of services in their offers (Table 8), whereas Cluster 2 consisted of $76 \%$ of manufacturers who provided less than ten types of services to their clients. Furthermore, Cluster 1 was dominated by manufacturers who offered fewer than ten service types. 
Table 8. Structure of each cluster in terms of the service offerings.

\begin{tabular}{cccc}
\hline Number of Services in the Offer & Cluster 1 & Cluster 2 & Cluster 3 \\
\hline Less than 10 different types & $65 \%$ & $76 \%$ & $35 \%$ \\
10 and more types & $35 \%$ & $24 \%$ & $65 \%$ \\
Sum & $100 \%$ & $100 \%$ & $100 \%$ \\
\hline
\end{tabular}

The last comparison of cluster elements concerned the company size and was performed to complete the profile of the manufacturers from each group. The results are presented in Table 9. Cluster 1 was dominated (42\%) by small enterprises. Cluster 2 consisted of $67 \%$ medium enterprises. Cluster 3 had twice as many large companies (22\%) compared to Cluster $2(9 \%)$.

Table 9. Structure of each cluster in terms of the size of the company.

\begin{tabular}{cccc}
\hline Size of the Company & Cluster $\mathbf{1}$ & Cluster 2 & Cluster 3 \\
\hline Large & $21 \%$ & $9 \%$ & $22 \%$ \\
Medium & $35 \%$ & $67 \%$ & $63 \%$ \\
Small & $42 \%$ & $21 \%$ & $13 \%$ \\
Micro & $2 \%$ & $3 \%$ & $2 \%$ \\
Sum & $100 \%$ & $100 \%$ & $100 \%$ \\
\hline
\end{tabular}

Thus, it may be concluded that Cluster 1 consisted of companies with somewhat vast service offers, but mostly product-oriented, which derived no more than $20 \%$ of their income from service provision and were mostly small or medium-sized enterprises. Cluster 2 included most manufacturers that did not provide any services to their clients and, consequently, gained no income from service provision. These companies were usually medium-sized. Finally, Cluster 3 was comprised of enterprises that achieved the highest financial benefits from services, offered the most extensive catalog of services to their clients, and were large or medium-sized. Major differences were found between the assessment of the importance of the studied factor on the servitization process by companies grouped in Clusters 2 and 3. The first group gave significantly lower assessments to some factors than the second. In light of the conducted analyses, an obvious link was found between the service provision experience of manufacturers and how they assessed the importance of studied factors. It would not be considered a mistake to assume that the level of servitization of Cluster 3 enterprises was higher, and they may have had more comprehensive knowledge about the factors determining this process.

To make profiles of each cluster more complete, the relationship between variables belonging to the cluster and a profile of production was examined. A variable profile of production was described based on the declaration of the respondent about the main manufacturing activity, i.e., the manufacturing of general-purpose machinery, special-purpose machinery, agriculture and forestry machinery, mechanical equipment and machines, and other machines (unclassified anywhere else). The analyzed variables were categorical (qualitative), so a chi-squared test and a correspondence analysis were appropriate. However, the chi-squared independence test did not confirm any statistically significant relationship between two analyzed variables, namely, belonging to the cluster and profile of production ( $p$-value was equal to 0.223 ). Therefore, there were no premises for the correspondence analysis. Thus, only a two-way table was built to reveal the structure of the cluster in terms of the production profile of its elements (Table 10). 
Table 10. Two-way table for variables belonging to the cluster and profile of production.

\begin{tabular}{ccccc}
\hline \multirow{2}{*}{ Profile of Production } & \multicolumn{3}{c}{ Number of Companies } \\
\cline { 2 - 5 } & Cluster 1 & Cluster 2 & Cluster 3 & Total \\
\hline Special-purpose machinery & 21 & 11 & 20 & 52 \\
General-purpose machinery & 31 & 10 & 16 & 57 \\
Mechanical equipment and machines & 3 & 6 & 7 & 16 \\
Agriculture and forestry machinery & 6 & 5 & 9 & 20 \\
Other machines & 1 & 1 & 3 & 5 \\
Total & 62 & 33 & 55 & 150 \\
\hline
\end{tabular}

Cluster 1 had the most manufacturers of general-purpose machines, whilst Cluster 3 hosted the largest number of manufacturers producing agriculture and forestry machinery and, also, other machines. But in general, the structures of all clusters were rather similar.

\subsection{Findings from In-Depth Interviews}

In-depth interviews were conducted to gain more information about factors considered crucial in the extension of service activity by machinery manufacturers and those that could significantly influence both a decision-making process and product-service integration in these companies.

One of the most important aspects pointed out by both business and scientific experts, were legal and political conditions in the field of service provision, standards and ordinances regulating the functioning of industry and the service sector, as well as the policy of the state, the European Union and other countries that could support or block servicing activities undertaken by entrepreneurs.

"Certainly, these external factors are political -I think this is an important factor. For example, the policies of the European Union and various types of regulations that affect individual sectors of the economy" (Expert No. 1).

"Legal factors, because for example, a person who is to deal with electrics and automation should have electrical qualifications" (Expert No. 10).

"Certainly, those political factors and any legal conditions that force various modernizations or actions" (Expert No. 9).

"Legal-because the manufacturer and the customer, having a given machine, are obliged to keep this machine, its operational condition, that it does not cause threats" (Expert No. 6).

Political factors also appeared in the opinions of experts as an internal aspect, i.e., in the context of the organization's policy and the adopted strategy for operation and strategic goals. Additionally, economics was a relatively important element affecting servitization, with the financial condition of the economy as well as the financial situation of enterprises and their clients being important. Social factors were also relatively important, among which much attention was paid to the availability of employees, their qualifications or licenses, and the level of knowledge they possessed:

"It is easier to buy technology at the moment than to get good employees" (Expert No.8).

"Employees who come to us have completed relevant schools and faculties, but for example, they do not have appropriate training and qualifications" (Expert No. 10).

"This knowledge-based society drives this service sector, ... in services, the human factor is more important than material factors, so knowledge is more important than work" (Expert No. 1).

Also, in the context of external social and economic factors, requirements and behavior of buyers were mentioned as well as the level of wealth of the society, and certain trends or fashion: 
"First, we need to know what customers' needs are in terms of services, whether customers actually want these complementary services or not. ... It is often said that today's consumers in Europe are postmodern consumers, and this postmodernism manifests in various consumer behaviors. These clients are trying completely new services, new experiences. ... I think that this trend may affect the fact that completely new services will be accepted by the market" (Expert No. 1).

"The customer is most important to us. And if there are no strictly technological or technical barriers to perform a given service, we are most open" (Expert No. 5).

"There is a fashion for ecology and ecological activities. So, apart from the fact that something is going on legally and there are legal conditions that, for example, it is forbidden to dispose of waste, the awareness itself in society is definitely incomparable today with what was about 10-20 years ago. It certainly matters. And it also positively affects our activities" (Expert No. 9).

Among internal conditions, special attention was also paid to the human factor, customer orientation and technical aspects, such as, for example, the technologies of manufactured products and the products themselves, as well as innovation, both in terms of technology and the innovativeness of enterprises in general:

"The type of our manufacturing activity just forces service activities. One can imagine, for example, that we would not provide the service on our own, but I do not think that it will succeed in the long term" (Expert No. 4).

"Technological factors unquestionably have a significant impact on the development of the servitization process, i.e., what the organization of production in a particular enterprise looks like, how automated it is, and to what extent it uses modern solutions. And this in effect will also require the entrepreneur to be involved in the services sector" (Expert No. 3);

"I think the level of innovation itself can be an important factor that will stimulate this process of servitization. Companies with a higher level of innovation will be able to offer higher quality services. If they have such combined, industrial, and service activities, they will be able to benefit from those innovations that they previously used in this industrial activity" (Expert No. 1).

One of the experts from the scientific community emphasized that internal factors were more important in the process of developing services in an enterprise and the organization should begin analyzes aimed at diagnosing the resources and capabilities of the enterprise for the needs of product and service integration:

"It seems that understanding the essence of the phenomenon of servitization or solutions primarily begins inside the company" (Expert No. 2).

In the opinion of some experts, many of these conditions intertwine, which is manifested in mutual dependencies and cause-and-effect relationships; therefore, it is sometimes difficult to analyze them separately or classify factors into a specific group. Asked about the hierarchy of factors by importance, experts mostly indicated long-lasting and stronger relationships, a strategy of the organization, legal regulations regarding the provision of long-term services, the economic benefits of service recipients, and the technical aspects connected with the manufacturing technology consumption of energy and materials throughout the product life-cycle.

\section{Discussion}

The analyses conducted showed that machinery manufacturing companies, for which the services constitute a significant part of their activity, have slightly different opinions on the importance of some factors that those who do not pay particular attention to service provision. Assumedly, their opinions 
about the factor importance in the process of servitization may be a consequence of their experience as service providers. Machinery manufacturers from this group (Cluster 3) far more frequently provided such services as transport, assembly and/or implementation, training and technical, maintenance and technical support, training and technical consultancy, modernization/renovation/regeneration, or research and expertise. So, they also had more frequent contacts and longer relationships with clients. These manufacturers gave high scores to the costs of delivery and the provision of services, technical aspects of the integration of production and service processes in the company, and relations with stakeholders and partners in service processes. All these aspects are connected directly with the actual functioning of the service delivery process in a company. For a beginner, when services are an add-on to a product offer and are rarely provided, technical organization of product and service integration or partnership with other stakeholders may appear irrelevant or easy to establish, and, thus, secondary compared to customer requirements or financial and non-financial benefits and barriers to service provision. In fact, services in the machinery manufacturing sector require appropriate technical infrastructure [55], integration of planning, designing, and delivering of product and service offerings [44] and building strong partnerships that enable the proper flow of a service process [41]. In the case of a manufacturing company, creating networks and alliances is often characterized by the lack of trust in network partners [56]. According to the study results, for manufacturers who have none or very limited experience in service provision, these factors seemed to be less important. If managers underestimate crucial determinants of the servitization process in a decision-making process and servitization strategy building, they pose an additional and unnecessary risk for its successful implementation. In the light of the study results, it is advisable to pay more attention to the opinions (factor assessment) of companies in Cluster 3 and carefully consider all nine factors affecting product and service integration in manufacturing companies.

Respondents were also asked (in an open question), whether there were some other factors significant in the process of servitization, which were not mentioned in the questionnaire. A total of $95 \%$ of respondents answered that all factors were indicated in the previous question. The remaining $5 \%$ of responses named "extensive positive experience", "tested safety standards", "respect for the product and customer", "caring for the quality confirmed by the certificate", and "mobility, professionalism, quality". The aspect of quality both in the context of manufactured products (safety standards, certificates) and provided services ("mobility, professionalism") or customer relations ("respect for the customer", "positive experience") appeared to be important.

During the qualitative study, experts indicated more specific determinants as the most important in extending the service activity by manufacturing companies, such as: (i) long-lasting and stronger relationships, (ii) organization strategy, (iii) legal regulations regarding the provision of long-term services, and (iv) economic benefits of service recipients. Generally, they mentioned all aspects that were included in the survey and assessed by machinery manufacturers, so they confirmed the results of the quantitative research. However, in some areas, they highlighted the importance of slightly different aspects. In the area of technical or technological organization of product-service integration, they underlined the level of innovation in the company as a factor that stimulated and determined the servitization process in a manufacturing company. In the area of social factors, they emphasized its internal dimension, in particular, employee competences and skills to cope with the challenge of more advanced relationships with customers. In fact, the importance of the intangible capital of a company seemed to grow in the context of rapid changes in every sector and market [57]. The author believes that the competencies of manufacturing organizations in product-service integration require a separate study and is a vital direction for further studies on factors determining product-service integration. But four key aspects listed above, which were considered by experts as the most important for product-service integration within a machinery manufacturing company, were in line with assessments of manufacturers from Cluster 3. These manufacturers considered relationships with different stakeholders as a crucial aspect in the servitization process (the mean assessment in the cluster of 6.8). They found legal conditions for the provision of services even more important (the importance 
assessed as 6.89 on average). Finally, in their view, economic aspects were a significant determiner of product-service integration (the mean value of assessment of 6.78). Thus, the entrepreneurs in Cluster 3 showed more comprehensive and extensive knowledge about the product-service integration, which was comparable to the knowledge of experts in the field. This is expressed in similar opinions on the key determinants of the servitization process in the machinery manufacturing sector.

Ultimately, some social implications result from the study. The servitization trend is gaining momentum in Poland and other countries. Not only is it triggered by the actions of manufacturers, but also by customer behavior changes. Experts noticed the need for new experiences in customer behavior, willingness to follow fashion and ecological trends. This may result in the acceptance and evolution of completely new services in the manufacturing sector. Thus, on the one hand, ecological awareness implies new customer behaviors. On the other hand, manufacturers who follow servitization trends encourage their clients to be more aware of the sustainable use of products. Also, considering the development of manufacturers into service providers, there is a need to adjust their human resources to the new activity. The skills of manufacturer employees must meet new requirements that are imposed by the higher level of relationships with partners and customers. Certainly, the so-called soft competencies gain importance in the industry sectors, which expand service activity. Employees must improve their social skills through training or mentoring so they could efficiently operate within the service provision.

\section{Conclusions}

The servitization of manufacturing is a trend that may be observed in most economies worldwide. It is widely discussed in the scientific literature in different contexts [58,59], and product-service offerings are perceived by many authors as a more sustainable solution compared to selling products only [60-62]. This triggers a need for extensive and far-reaching changes in many aspects of business activity. In this paper, factors that are crucial in the servitization of manufacturing were investigated using the example of Polish market conditions and the perspective of Polish machinery manufacturers. Therefore, all conclusions drawn for the study are relevant to machinery manufacturers.

The overview of the literature shows that many determinants influence servitization processes. They were cataloged into nine general factors and included in the survey of Polish machinery manufacturers. The factors were as follow:

- Customer requirements and preferences;

- Added value for the customer and the company;

- Economic and financial analysis;

- Relations, stakeholders and partners in service processes;

- Costs of delivery and provision of services;

- Technical organization of service processes;

- Technical and organizational aspects of the integration of production and service processes;

- Ecological aspects of production and service activities;

- Legal conditions for the provision of services.

The analysis of survey outcomes leads to the conclusion that each of the indicated factors was confirmed to be crucial in the servitization process. A detailed analysis revealed that there were significant differences in the assessment of some factor by the manufacturers who had none or limited experience in service provision and rather standard service offerings (no more than ten different forms of services), and those who derived a relatively higher income from service provision and delivered more extended packages of services to their clients. The first group (Cluster 2) considered three factors having rather low importance, namely, relations, stakeholders and partners in service processes; the costs of delivery and provision of services; and the technical and organizational aspects of the integration of production and service processes. The second group (Cluster 3) thought these factors as highly important, and their opinions were consistent with those of experts. Therefore, it is advisable 
to follow their judgments while considering and planning the integration of products and services. As the factors were formulated on the high level of generality, in-depth interviews were carried out to support the research. In general, the experts confirmed the results of the quantitative research, pointing out the importance of all kinds of studied factors: legal, social, economic, ecological, technical, and values. Additionally, for some areas, they highlighted the importance of other aspects, which seemed to be a promising research challenge for future studies.

This paper addresses a particularly up-to-date and pressing research problem. Although it is advisable to conduct further research with a more detailed catalog of factors, the results of the study presented in this paper are a valuable contribution to the research field of product-service integration. First, the most important aspects were identified for the manufacturer to analyze at the beginning of the servitization path. Second, differences of opinion were found among manufacturers who had diverse experience in service provision. This undoubtedly indicates that during the servitization process, the perception of determinants changes, and that at the beginning, some factors and conditions might be underestimated by the manufacturers. The opinions of manufacturers who are more experienced in service provision are a reliable and helpful guide for managers who begin the extension of activity into service provision and face difficult decision-making problems with planning and designing the servitization in their companies. This information may be of great value for managers who are considering starting or have already started the journey toward servitization. However, it is impossible to explain clearly the reasons behind the managers' decisions without more extensive research in this area. Thus, aspects such as the attitude of managers to market group developments or the difference in development dynamics, seems to be a promising direction for further research.

The author is fully aware of the study limitations. The research sample was limited to a certain sector and the Polish market. The study only focused on the perspective manufacturers. Respondents expressed the importance of each aspect using a seven-point scale as their subjective opinion, so the measurability of the factors seems moderate. To provide a complete picture representing the meaning of the phenomenon of servitization, a customer perspective should be examined. Furthermore, the factors were formulated using a high level of generality. This could have led to different perceptions and understandings from the respondents. It is also difficult to compare the study findings with other international studies because, to the best of the author's knowledge, no similar study has been carried out, or simply was not identified in the literature. Either way, this is an obvious disadvantage of the study. Nevertheless, in the author's opinion, the advantage of the research is certainly its originality. The revealed differences in manufacturer opinions about the factors influencing the servitization process seem to be related to their experience in service provision. As a result of the quantitative study, it was proved that some aspects of product and service integration gained importance with the development of service activity. The study results give an interesting insight into the research field of manufacturing servitization by providing a more general picture of the analyzed phenomenon, and, hence, may constitute a background and prerequisite for further research.

Funding: This research was funded by the National Science Centre, Poland, grant number 2016/23/N/HS4/03547. The research was conducted within the scientific project "Methodology of strategic analysis of the company for the purposes of product-service integration".

Conflicts of Interest: The author declares having no conflict of interest.

\section{References}

1. Qi, Y.; Mao, Z.; Zhang, M.; Guo, H. Manufacturing practices and servitization: The role of mass customization and product innovation capabilities. Int. J. Prod. Econ. 2020, 228, 107747. [CrossRef]

2. Lightfoot, H.; Baines, T.; Smart, P. The servitization of manufacturing. A systematic literature review of independent trends. Int. J. Oper. Prod. Manag. 2013, 33, 1408-1434. [CrossRef]

3. Robinson, T.; Clarke-Hill, C.M.; Clarkson, R. Differentiation through service: A perspective from the commodity chemicals sector. Serv. Ind. J. 2002, 22, 149-166. [CrossRef] 
4. Ren, G.; Gregory, M.J. Servitization in manufacturing companies: A conceptualization, critical review and research agenda. In Proceedings of the 16th Frontiers in Service Conference, San Francisco, CA, USA, 4-7 October 2007.

5. Matschewsky, J. Unintended Circularity?-Assessing a Product-Service System for its Potential Contribution to a Circular Economy. Sustainability 2019, 11, 2725. [CrossRef]

6. Ulaga, W.; Reinartz, W.J. Hybrid Offerings: How Manufacturing Firms Combine Goods and Services Successfully. J. Mark. 2011, 75, 5-23. [CrossRef]

7. Dainty, A. Achieving value through Product-Service integration: Context and challenges. In CIB Priority Theme-Revaluing Construction: A W065 'Organisation and Management of Construction' Perspective; Sexton, M., Kähkönen, K., Lu, S., Eds.; CIB General Secretariat: Rotterdam, The Netherlands, 2007; Volume 313, pp. 45-53.

8. Lightfoot, H.W.; Baines, T.; Smart, P. Examining the information and communication technologies enabling servitized manufacture. Proc. Inst. Mech. Eng. B J. Eng. 2011, 225, 1964-1968. [CrossRef]

9. Ahamed, Z.; Inohara, T.; Kamoshida, A. The servitization of Manufacturing: An Empirical Case Study of IBM Corporation. Int. J. Bus. Adm. 2013, 4, 18-26. [CrossRef]

10. Kozłowska, J. Product-Service System in a manufacturing company strategy-A review paper. Econ. Manag. 2015, 7, 48-56.

11. Gierej, S. Techniques for designing value propositions applicable to the concept of outcome-economy. Eng. Manag. Prod. Serv. 2017, 9, 56-63. [CrossRef]

12. Shelton, R. Integrating product and services innovation. Res. Technol. Manag. 2009, 52, 38-44. [CrossRef]

13. Meier, H.; Roy, R.; Seliger, G. Industrial Product-Service Systems-IPS2. CIRP Ann. Manuf. Technol. 2010, 59, 607-627. [CrossRef]

14. Xerox 2013 Annual Report. Available online: http://www.xerox.com/annualreport/2013/assets/xerox-oar2013-full.pdf (accessed on 23 March 2019).

15. Neely, A.D. Exploring the Financial Consequences of the Servitization of Manufacturing. Oper. Manag. Res. 2009, 1, 103-118. [CrossRef]

16. Kohtamäki, M.; Einola, S.; Robetino, R. Exploring servitization through the paradox lens: Coping practices in servitization. Int. J. Prod. Econ. 2020, in press.

17. Meier, H. Planning and Development of Industrial Product-Service Systems. In The Philosopher's Stone for Sustainability, Proceedings of the 4th CIRP International Conference on Industrial Product-Service Systems, Tokyo, Japan, 8-9 November 2012; Shimomura, Y., Kimita, K., Eds.; Springer: Berlin, Germany, 2012; pp. 13-18.

18. Nemoto, Y.; Akasaka, F.; Shimomura, Y. A Knowledge-Based Design Support Method for Product-Service Contents Design. In The Philosopher's Stone for Sustainability, Proceedings of the 4th CIRP International Conference on Industrial Product-Service Systems, Tokyo, Japan, 8-9 November 2012; Shimomura, Y., Kimita, K., Eds.; Springer: Berlin, Germany, 2012; pp. 49-54.

19. Pezzotta, G.; Cavalieri, S.; Gaiardelli, P. A spiral process model to engineer a product service system: An explorative analysis through case studies. CIRP J. Manuf. Sci. Technol. 2012, 5, 214-225. [CrossRef]

20. Huxtable, J.; Schaefer, D. On servitization of the manufacturing industry in the UK. Proceedia CIRP 2016, 52, 46-51. [CrossRef]

21. Mastrogiacomo, L.; Barravecchia, F.; Franceschini, F. A general overview of manufacturing in Italy. Procedia CIRP 2017, 64, 121-126. [CrossRef]

22. SantaMaria, L.; Nieto, M.J.; Miles, I. Service innovation in manufacturing firms: Evidence from Spain. Technovation 2012, 32, 144-155. [CrossRef]

23. Matusek, M. Łańcuch dostaw zintegrowanych rozwiązań produktowo-usługowych-studium przypadku (Eng. The supply chain of integrated product and service solutions-a case study). Zesz. Nauk. Politech. Śląskiej Ser. Organ. Zarzadzanie 2017, 101, 325-338. (In Polish)

24. Kozłowska, J. Services in Machinery Manufacturing Sector in Poland. Procedia Eng. 2017, 182, $354-358$. [CrossRef]

25. Kozłowska, J. Servitization of Manufacturing Companies-a Proposition of Factors for STEEPVL Analysis. In Economic and Social Development (Book of Proceedings), 23rd International Scientific Conference on Economic and Social Development (ESD), Madrid, Spain, 15-16 September 2017; Cingula, M., Przygoda, M., Detelj, K., Eds.; Varazdin Development and Entrepreneurship Agency: Varazdin, Croatia, 2017; pp. 619-628.

26. Oliva, R.; Kallenberg, R. Managing the transition from products to services. Int. J. Serv. Ind. Manag. 2003, 14, 160-172. [CrossRef] 
27. Kołaczek, P. Rozwój Przemysłu Maszynowego w Polsce-Raport (Eng. Development of the Machine Industry in Poland-Report). Mitsubishi Electric Europe, B.V., 2018. Available online: https://iautomatyka.pl/rozwojprzemyslu-maszynowego-w-piolsce-raport/ (accessed on 20 February 2020). (In Polish).

28. Baines, T.S.; Lightfoot, H.W.; Evans, S.; Neely, A.; Greenough, R.; Peppard, J.; Roy, R.; Shehab, E.; Braganza, A.; Tiwari, A.; et al. The state-of-the-art in Product Service Systems. Proc. Inst. Mech. Eng. B J. Eng. 2007, 221, 1543-1552. [CrossRef]

29. Aurich, J.C.; Mannwejler, C.; Schweitzer, E. How to design and offer services successfully. CIRP J. Manuf. Sci. Technol. 2010, 2, 136-143. [CrossRef]

30. Cook, M.; Bhamra, T.; Lemon, M. The transfer and application of Product Service-systems: From academia to UK manufacturing firms. J. Clean. Prod. 2006, 14, 1455-1465. [CrossRef]

31. Mont, O. Clarifying the concept of product-service system. J. Clean. Prod. 2002, 10, 237-245. [CrossRef]

32. Lindahl, M.; Sundin, E.; Sakao, T. Environmental and economic benefits of Integrated Product Service Offerings quantified with real business cases. J. Clean. Prod. 2014, 64, 288-296. [CrossRef]

33. Ceci, F.; Masini, A. Balancing specialized and generic capabilities in the provision of integrated solutions. Ind. Corp. Chang. 2011, 20,91-132. [CrossRef]

34. Fliess, S.; Lexutt, E. How to be successful with servitization-Guidelines for research and management. Ind. Mark. Manag. 2019, 78, 58-75. [CrossRef]

35. Schnürmacher, C.; Hayka, H.; Stark, R. Providing Product-Service-Systems-The Long Way from a Product OEM towards an Original Solution Provider (OSP). Procedia CIRP 2015, 30, 233-238. [CrossRef]

36. Matusek, M. Innowacje usług w przedsiębiorstwach produkcyjnych-czynniki sukcesu (Eng. Service innovations in manufacturing companies-Success factors). Zesz. Nauk. Politech. Śląskiej Ser. Organ. Zarzadzanie 2015, 83, 427-436. (In Polish)

37. Windahl, C.; Lakemond, N. Developing integrated solutions: The importance of relationships within the network. Ind. Mark. Manag. 2006, 35, 806-818. [CrossRef]

38. Valtakoski, A. Explaining servitization failure and deservitization: A knowledge-based perspective. Ind. Mark. Manag. 2017, 60, 138-150. [CrossRef]

39. Gesing, J.; Maiwald, K.; Wieseke, J.; Sturm, R. Are IPS2 always a Solution? Obstacles towards Buying Industrial Product Service Systems. Procedia CIRP 2014, 16, 265-270. [CrossRef]

40. Ziout, A.; Azab, A. Industrial Product Service System: A case Study from the Agriculture Sector. Procedia CIRP 2015, 33, 64-69. [CrossRef]

41. Mathieu, V. Service strategies within the manufacturing sector: Benefits, costs and partnership. Int. J. Serv. Ind. Manag. 2001, 12, 451-475. [CrossRef]

42. Marsh, S.J.; Stock, G.N. Building dynamic capabilities in new product development through intertemporal integration. J. Prod. Innov. Manag. 2003, 20, 136-148. [CrossRef]

43. Tukker, A.; Tischner, U. (Eds.) New Business for Old Europe-Product-Service Development, Competitiveness and Sustainability; Greanleaf Publishing: Sheffield, UK, 2006.

44. Aurich, J.; Fuchs, C.; DeVries, M.F. An Approach to Life Cycle Oriented Technical Service Design. CIRP Ann. Manuf. Technol. 2004, 53, 151-154. [CrossRef]

45. StatSoft Electronic Textbook. Available online: https://www.statsoft.pl/textbook/stathome.html (accessed on 12 February 2012).

46. Gordon, A.D. Classification, 2nd ed.; Chapman \& Hall/CRC: Boka Raton, FL, USA, 1999.

47. Everitt, B.S.; Landau, S.; Leese, M. Cluster Analysis; Oxford University Press Inc.: New York, NY, USA, 2001.

48. Jarocka, M. University Ranking Systems-From League table to Homogeneous Groups of Universities. Int. Sch. Sci. Res. Innov. 2012, 6, 1377-1382.

49. Nazarko, J.; Chodakowska, E.; Jarocka, M. Segmentacja szkół wyższych metodą analizy skupień versus konkurencja technologiczna ustalona metodą DEA- studium komparatywne (Eng. Segmentation of higher education institutions by cluster analysis versus technological competition determined by the DEA methodcomparative study). Pr. Nauk. Uniw. Ekon. Wroctawiu Taksonomia 2012, 242, 163-172. (In Polish)

50. Wałęga, A.; Krzanowski, S.; Chmielowski, K. Wykorzystanie metody analizy skupień do identyfikacji jednorodnych zlewni pod względem indeksów powodziowości i wybranych charakterystyk fizjograficznych (Eng. Method of cluster analysis in homogenous catchments identification considering flood indexes and selected physiographic characteristics). Pol. Akad. Nauk Odzdział Krakowie 2009, 6, 67-81. (In Polish) 
51. Misztal, M. O zastosowaniu kanonicznej analizy korespondencji w badaniach ekonomicznych (Eng. On the use of canonical correspondence analysis in economic research). Pr. Nauk. Uniw. Ekon. Wrocławiu Taksonomia 24 Klasyf. Anal. Danych Teor. Zastos. 2015, 384, 200-208. (In Polish)

52. Greenacre, M.J. Correspondence Analysis in Practice; Academic Press: London, UK, 1993.

53. Błaczkowska, A.; Grześkowiak, A.; Król, A.; Stanimir, A. Wykorzystanie analizy korespondencji w badaniu czynników różnicujących wyniki z dwóch części egzaminu gimnazjalnego uzyskanych przez uczniów $z$ różnych obszarów terytorialnych (Eng. The use of correspondence analysis in the study of factors differentiating the results of two parts of the junior high school exam obtained by students from different territorial areas). Przeglad Stat. 2012, 59, 163-178. (In Polish)

54. Górniak, J. Zastosowanie analizy korespondencji w badaniach społecznych i marketingowych (Eng. The use of correspondence analysis in social and marketing research). ASK Res. Methods 2000, 9, 115-134. (In Polish)

55. Williams, A. The Strategic Management of Product Service Systems; BRASS Centre: Cardiff, UK, 2005; pp. $20-21$.

56. Goedkoop, M.J.; van Halen, J.G.; Riele, R.M.; Rommers, J.M. Product Service Systems, Ecological and Economic Basics. Available online: http://teclim.ufba.br/jsf/indicadores/holan\%20Product\%20Service\% 20Systems\%20main\%20report.pdf (accessed on 15 April 2020).

57. Buchelt, B.I.; Frączkiewicz-Wroka, A.; Kaminska, R. Key determinants of human resource management in hospitals: Stakeholder perspective. Eng. Manag. Prod. Serv. 2017, 9, 105-115. [CrossRef]

58. Kozłowska, J. The concept of products and services integration-Analysis of Scientific Publications. Bus. Manag. Educ. 2016, 14, 89-102. [CrossRef]

59. Kryvinska, N.; Kaczor, S.; Strauss, C. Enterprises' Servitization in the First Decade-Retrospective Analysis of Back-End and Front-End Challenges. Appl. Sci. 2020, 10, 2957. [CrossRef]

60. Vezolli, C.; Kothala, C.; Srinivasan, A. Product-Service System Design for Sustainability; Greenleaf Publishing: Sheffield, UK, 2014.

61. Maxwell, D.; Sheate, W.; van der Vorst, R. Functional and systems aspects of the sustainable product and service development approach for industry. J. Clean. Prod. 2006, 14, 1466-1479. [CrossRef]

62. Michelini, G.; Moraes, R.N.; Cunha, R.N.; Costa, J.M.H.; Ometto, A.R. From linear to circular economy: PSS conducting the transition. Procedia CIRP 2017, 64, 2-6. [CrossRef]

(C) 2020 by the author. Licensee MDPI, Basel, Switzerland. This article is an open access article distributed under the terms and conditions of the Creative Commons Attribution (CC BY) license (http://creativecommons.org/licenses/by/4.0/). 